\title{
Bacillus firmus-Bacillus lentus: a Series or One Species?
}

\author{
RUTH E. GORDON, JEAN L. HYDE, AND JOHN A. MOORE, JR. \\ Waksman Institute of Microbiology, Rutgers University, The State University of New Jersey, Piscataway, \\ New Jersey 08854
}

\begin{abstract}
The 46 strains of Bacillus firmus and Bacillus lentus in our collection were found to share a group of 17 physiological properties that distinguished them from morphologically similar strains of other species of the genus Bacillus. Thirteen other characteristics separated the 46 strains into one group of 20 similar to the nomenclatural type strain of $B$. firmus (ATCC strain 14575) and a second group of eight strains resembling the nomenclatural type strain of $B$. lentus (ATCC strain 10840). The pattern of these 13 additional characteristics of the remaining 18 of the 46 strains fell between the two groups. Guanine plus cytosine content in the deoxyribonucleic acid of 31 of the 46 strains ranged from 39.0 to $48.3 \mathrm{~mol} \%$ and did not allow separation of the strains into distinct groups. The 46 strains of our collection could not, therefore, be cleanly divided by the properties tested and appeared as a spectrum, or series, of strains.
\end{abstract}

Bacillus firmus, described and named by Werner (18), is an accepted species of the genus Bacillus, and its nomenclatural type strain is the American Type Culture Collection (ATCC) strain 14575 (6). In 1935 Gibson (5) characterized a new species, Bacillus lentus, in a description of nine isolates from five different soils. He separated his nine strains of $B$. lentus from strains of $B$. firmus by their production of urease and their failure to decompose casein and gelatin.

In a study of the nutritional requirements of strains of Bacillus spp., Proom and Knight (13) examined 20 strains of $B$. firmus and six of $B$. lentus. They reported that the strains of the two species could not be separated by their nutritional requirements; the most exacting strains of $B$. firmus and the least exacting strains of $B$. lentus had the same requirement for amino acids, thiamine, and biotin. This investigation of our 46 strains representing $B$. firmus and $B$. lentus confirmed the spectrumlike relationship of the strains observed by Proom and Knight.

\section{MATERIALS AND METHODS}

Organisms. The 46 strains examined were listed by Gordon et al. (7, p. 190) and are also presented in Table 1. The first of these strains (NRS 613) was acquired in 1937, and the last strain (NRS 1576) was added to our collection in 1962.

Resistance to lysozyme. Lysozyme solution was prepared by dissolving $0.1 \mathrm{~g}$ of lyophilized lysozyme $(6,000$ to $10,000 \mathrm{U} / \mathrm{mg}$ from Nutritional Biochemicals Corp., Cleveland, Ohio) in $100 \mathrm{ml}$ of distilled water in a volumetric flask and sterilizing the solution by filtration through a $0.2-\mu \mathrm{m}$ membrane filter. A $1-\mathrm{ml}$ volume of this filtrate and $99 \mathrm{ml}$ of sterile nutrient broth were mixed aseptically and dispensed in 2.5$\mathrm{ml}$ amounts in sterile plugged tubes. This broth containing 60 to $100 \mathrm{U}$ of lysozyme per $\mathrm{ml}$ and a control tube of nutrient broth without lysozyme were inoculated with a small loopful of a culture in nutrient broth ( 7 to 14 days old) for each organism tested. Growth was recorded after 7 and 14 days of incubation at $28^{\circ} \mathrm{C}$.

Liquefaction of gelatin. Cultures were inoculated into tubes of nutrient gelatin (nutrient broth, 100 $\mathrm{ml}$; Difco gelatin, $12 \mathrm{~g} ; \mathrm{pH} \mathrm{7.0)}$ and incubated at $28^{\circ} \mathrm{C}$ for 14 days. After they had been cooled to $4^{\circ} \mathrm{C}$, they were observed for liquefaction of the gelatin.

Formation of urease. The medium of Collins (3) was modified for detection of urease and as used here contained the following: peptone, $0.1 \mathrm{~g} ; \mathrm{NaCl}$, $0.5 \mathrm{~g} ; \mathrm{KH}_{2} \mathrm{PO}_{4}, 0.2 \mathrm{~g} ; 0.04 \%$ aqueous solution of phenol red, $2 \mathrm{ml}$; distilled water, $100 \mathrm{ml}$. Tubes with $2.5 \mathrm{ml}$ of this broth and a flask containing $100 \mathrm{ml}$ of it were sterilized by autoclaving. A $10-\mathrm{ml}$ volume of a $20 \%$ aqueous solution of urea sterilized by filtration was added to the flask and dispensed in 2.5-ml amounts in sterile tubes. Cultures were inoculated into tubes with and without urea, incubated at $28^{\circ} \mathrm{C}$, and compared at 1,3, and 7 days. Alkaline color of the indicator in tubes with urea in contrast to the color of the control tubes was accepted as evidence of the presence of urease.

A culture of $B$. lentus (ATCC 10840), known to be urease positive, and a culture of $B$. firmus (ATCC 14575 ), known to be urease negative, were used as controls.

Acid production from carbohydrates. The basal ammonium phosphate agar described by Gordon et al. (7) and nutrient agar with $3 \% \mathrm{NaCl}$ and $0.008 \%$ phenol red were used as substrates. Each carbohydrate was sterilized separately by autoclaving $\left(121^{\circ} \mathrm{C}\right.$ for $\left.20 \mathrm{~min}\right)$ in $10 \%$ aqueous solution, cooled, and added immediately in $0.5-\mathrm{ml}$ amounts to the tubes of sterile substrates $(7 \mathrm{ml}$ ). (In their studies of the genus Bacillus, Smith et al. $[15,16]$ used carbo- 
TABLE 1. History of strains of the Bacillus firmusBacillus lentus series

\begin{tabular}{|c|c|}
\hline $\begin{array}{l}\text { NRS strain }{ }^{a} \\
\text { no. }\end{array}$ & $\begin{array}{l}\text { Source, strain no., and name when re- } \\
\text { ceived }\end{array}$ \\
\hline 613 & $\begin{array}{l}\text { J. R. Porter, Univ. of Iowa } \leftarrow \text { G. Brede- } \\
\text { mann; B. firmus }\end{array}$ \\
\hline 670,1262 & $\begin{array}{l}\text { T. Gibson, Univ. of Edinburgh, strains } \\
165,238 ; B \text {. lentus }\end{array}$ \\
\hline 854 & $\begin{array}{l}\text { J. R. Porter, Univ. of Iowa } \leftarrow \text { G. Brede- } \\
\text { mann, strain A-Hamburg; B. firmus }\end{array}$ \\
\hline 1119 & $\begin{array}{l}\text { C. E. ZoBell, Scripps Inst., strain } 562 ; B \text {. } \\
\text { imomarinus }\end{array}$ \\
\hline 1131,1132 & $\begin{array}{l}\text { W. H. Fuller, Iowa State Univ.; unidenti- } \\
\text { fied isolations }\end{array}$ \\
\hline $\begin{array}{l}1147 \text { to } 1149 \\
1151,1152\end{array}$ & $\begin{array}{l}\text { H. W. Reuszer, Tropical Deterioration } \\
\text { Lab., U. S. Army, strains 692, 1098, } \\
\text { 1124, 1099, 719; unidentified isolations }\end{array}$ \\
\hline 1329 & $\begin{array}{l}\text { M. B. Allen, Hopkins Marine Station; } B \text {. } \\
\text { firmus }\end{array}$ \\
\hline 1369,1370 & $\begin{array}{l}\text { G. Pacheco, Inst. Oswaldo Cruz, strains S, } \\
\text { R; B. firmus (Pacheco and Santos, 12) }\end{array}$ \\
\hline 1560 to 1574 & $\begin{array}{l}\text { M. Turner, Univ. of Nottingham, SM } \\
\text { strains } 9,10,13,14,22,23,24,25,26,27, \\
29,30,31,33,34 \text {; unidentified isolations } \\
\text { from a salt marsh (17) }\end{array}$ \\
\hline 1575,1576 & $\begin{array}{l}\text { J. M. Sieburth, Univ. of Rhode Island, } \\
\text { strains PJ 1, PJ } 3 \text {; unidentified isola- } \\
\text { tions from sea water }\end{array}$ \\
\hline
\end{tabular}

a Strains from the collection of the late N. R. Smith, U. S. Department of Agriculture.

hydrate solutions sterilized by filtration and by autoclaving. The solutions sterilized by both methods gave the same results.) Cultures on slants of these agars were incubated at $28^{\circ} \mathrm{C}$ and observed for the acid color of the indicators at 7 and 14 days.

Lysis by bacteriophage. A bacteriophage for ATCC strain 14575 of $B$. firmus was isolated by adding $3 \mathrm{~g}$ of garden soil to $100 \mathrm{ml}$ of a nutrient broth culture of ATCC 14575 in the log phase of growth. After incubation at room temperature for 3 days, the culture was filtered through a $0.45-\mu \mathrm{m}$ membrane filter. Dilutions $\left(10^{-2}\right.$ to $\left.10^{-5}\right)$ of this filtrate were mixed with $7 \mathrm{ml}$ of culture (in the log phase) and swabbed on plates of nutrient agar. For the preparation of a stock solution of the phage, material from a single isolated plaque from one of the plates was inoculated into a young broth culture and then repeatedly filtered and mixed with more host culture until lysis was observed in a broth culture of ATCC 14575 inoculated with a $10^{-\theta}$ idilution of the stock phage.

Sensitivity of the strains to this bacteriophage was demonstrated by smearing the surface of three $60-\mathrm{mm}$ plates of nutrient agar with a sterile swab dipped into an 18- to 24-h culture in nutrient broth (a fresh swab for each plate). A drop of the phage filtrate was placed on the swabbed agar surface of two plates, and a drop of sterile nutrient broth was placed on the surface of the third plate (control). Sensitivity of the strains to the phage was measured by the appearance of plaques or significantly less growth of the host lawn where the phage suspension had been dropped.

DNA base composition. For determination of guanine-plus-cytosine $(G+C)$ content in the deoxyribo- nucleic acid (DNA) of the strains, cells were grown to the late $\log$ phase in shake flasks of Trypticase soy broth (BBL) with or without additional $2 \% \mathrm{NaCl}$, depending on a preliminary comparison of growth of the culture in the two media. The DNA was prepared by the method of Marmur (9) and the thermal melting profile of each sample of DNA was determined spectrophotometrically by the procedure of Marmur and Doty (10). Moles percent of $\mathrm{G}+\mathrm{C}$ was calculated from the midpoint of the profile.

Preparation of spores for scanning electron photomicroscopy. Untreated spores were taken directly from abundantly sporulating cultures on slants of soil extract agar for examination by scanning electron microscopy (SEM). Spore suspensions were also treated with various concentrations of lysozyme (2) or of lysozyme with trypsin. Other spores were shaken with glass beads or subjected to sonic extraction. They were also extracted with an aqueous twophase polymer system using polyethylene glycol and potassium phosphate (14) or repeatedly washed with distilled water.

Spores were suspended in a drop of sterile distilled water on a cover slip and air-dried. The cover slip was mounted on a stub; the spores were coated with gold and examined in an ETEC Autoscan SEM System (Etec Corp., Hayward, Calif.).

Remaining tests. The other media and methods used were those of Gordon et al. (7, p. 3-14).

\section{RESULTS}

Microscopically, cells of 36 of the 46 strains, grown on soil extract agar for 1 or 2 days at $28^{\circ} \mathrm{C}$, were approximately $0.7 \mu \mathrm{m}$ in diameter with rounded ends and uniformly staining protoplasm. They were gram positive and motile. Their spores were ellipsoidal or cylindrical, central or paracentral, occasionally subterminal, and did not swell the sporangia appreciably. This description also applies to the cells and spores of strains of the subtilis-group (Bacillus licheniformis, Bacillus subtilis, and Bacillus pumilus) and of some strains of Bacillus coagulans.

The 10 strains whose cells did not resemble in size those of the subtilis-group were NRS strains 1149,1370 , and 1565 , whose cells were approximately $1.0 \mu \mathrm{m}$ in diameter, and 7 of 17 strains isolated from a salt marsh or seawater whose cells were of the same diameter as that of cells of the subtilis-group but were longer and often filamentous. The spores of these 10 strains, like those of the subtilis-group, were ellipsoidal or cylindrical, central or paracentral, and swelled the sporangia only slightly if at all.

Cultures of 17 strains referred to above (NRS 1560 to 1576) were received in 1962 as isolations from a salt marsh or from seawater (17). When first cultivated on soil extract agar without added $\mathrm{NaCl}$, they produced pleomorphic rods, 
approximately $1.2 \mu \mathrm{m}$ in diameter, filaments, and shadow forms. The cells resembled those of nutritionally unsatisfied cultures. Upon continued cultivation on soil extract agar, the cells gradually decreased in diameter. After 14 years, cells of 9 of the 17 strains resembled cells of the subtilis-group in diameter and length; cells of 7 strains, as previously stated, had the same diameter but were longer than typical cells of the subtilis-group; and cells of 1 strain (NRS 1565) were approximately $1.0 \mu \mathrm{m}$ in diameter. Cultures of all 17 strains sporulated during the first years of cultivation on soil extract agar. After 14 years, however, only 10 of the 17 continued to sporulate.

Spore surfaces of 9 of the 46 strains (NRS 749, $783,855,858,860,861,883,1070$, and 1131) were found to be smooth (Fig. 1) in accordance with the observations of Bradley and Franklin (1). Various attempts to remove the coating apparently covering all the spores were ineffective, and our best photographs were of spores taken directly from the agar slants.
Macroscopically, growth of the 46 cultures on agar was soft, smooth, and usually nonpigmented, but the 17 isolations from a salt marsh or seawater and NRS strain 749 exhibited yellow, pale orange, or salmon pink pigment.

The 46 strains examined shared a distinctive pattern of physiological reactions (Table 2). Positive characteristics of a typical strain (for example, ATCC 14575) were formation of catalase, hydrolysis of starch, production of acid from glucose and mannitol (basal ammonium phosphate agar plus the carbohydrate), growth in $7 \% \mathrm{NaCl}$, and growth at $35^{\circ} \mathrm{C}$. Negative characteristics were the V-P and egg-yolk reactions, anaerobic growth, growth on Sabouraud dextrose agar and/or broth, resistance to lysozyme, utilization of citrate and propionate, decomposition of tyrosine, production of dihydroxyacetone, and growth at $50^{\circ} \mathrm{C}$. The most useful of these properties for the separation of strains of the $B$. firmus- $B$. lentus series from strains of the subtilis-group are presented in Table 3.

Other tests applied to the 46 strains were acid

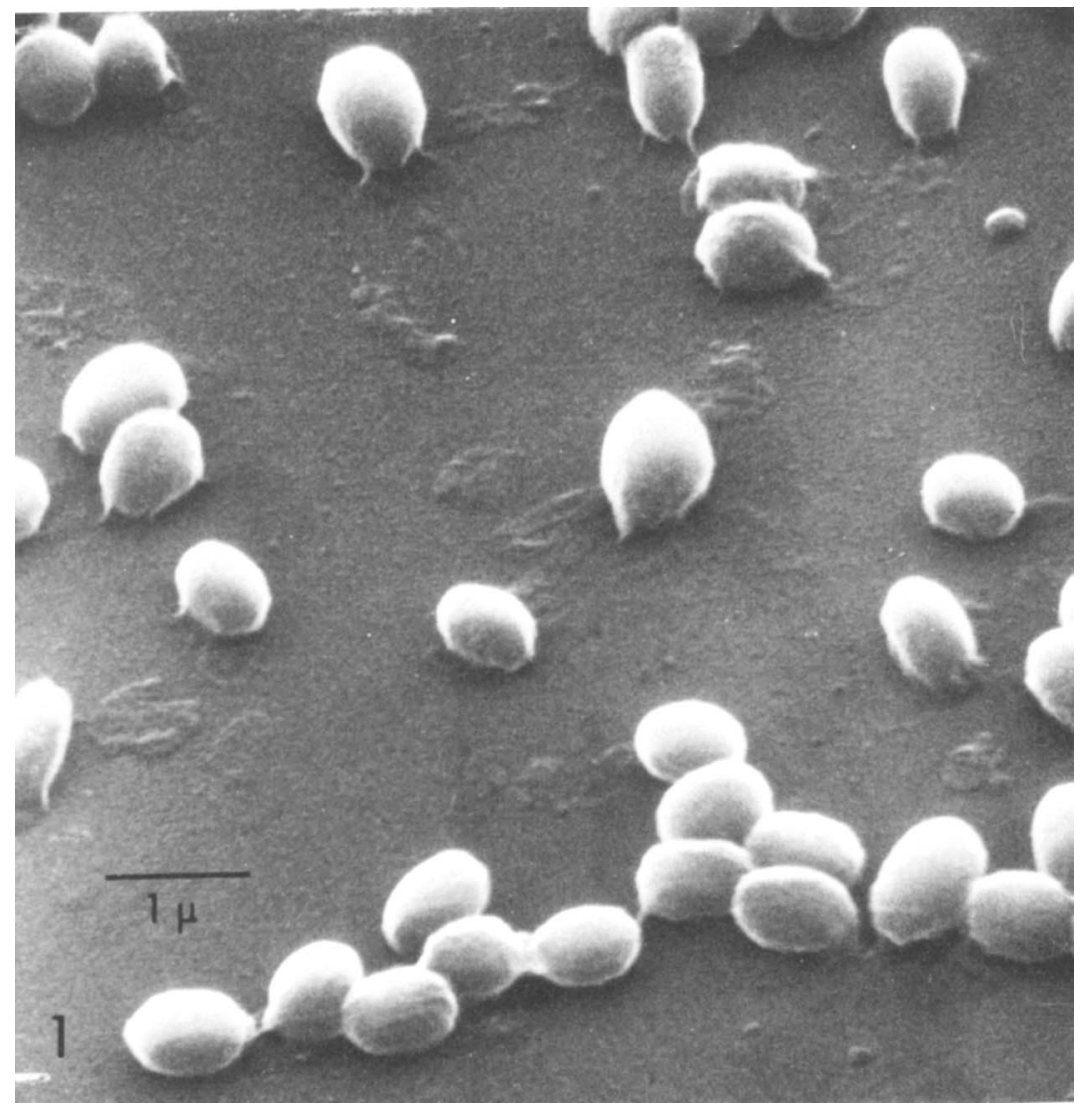

FIG. 1. Scanning electron photomicrograph of spores of NRS strain 749, a B. firmus-B. lentus intermediate. 
production from arabinose, mannose, melibiose, raffinose, sorbitol, sucrose, and xylose (with nutrient agar containing $3 \% \mathrm{NaCl}$ and phenol red as the substrate) and sensitivity to a bacteriophage for ATCC strain 14575. Gibson's (5) three tests for separating $B$. firmus and $B$. lentus (decomposition of casein and gelatin and production of urease) were also used as well as reduction of nitrate to nitrite and deamination of phenylalanine (Table 4). The nomenclatural type strain of $B$. firmus (ATCC 14575) and 19 other strains produced acid from only one (sucrose) of the seven carbohydrates; they were

TABLE 2. Some physiological properties of strains of the Bacillus firmus-Bacillus lentus series

\begin{tabular}{|c|c|c|}
\hline Property & $\begin{array}{c}46 \\
\text { strains } \\
\text { (\% posi- } \\
\text { tive) }\end{array}$ & $\begin{array}{l}\text { Typical } \\
\text { strain }\end{array}$ \\
\hline \multicolumn{3}{|l|}{ Production of: } \\
\hline Acetoin & 0 & - \\
\hline Catalase & 100 & + \\
\hline Dihydroxyacetone & 0 & - \\
\hline Hydrolysis of starch & 100 & + \\
\hline Anaerobic growth & 0 & - \\
\hline Egg-yolk reaction & 0 & - \\
\hline \multicolumn{3}{|l|}{ Acid from: } \\
\hline Glucose & 100 & + \\
\hline Mannitol & 93 & + \\
\hline \multicolumn{3}{|l|}{ Growth in: } \\
\hline $7 \% \mathrm{NaCl}$ & 85 & + \\
\hline $\begin{array}{l}\text { Sabouraud dextrose } \\
\text { broth }\end{array}$ & 0 & - \\
\hline $\begin{array}{l}\text { Sabouraud dextrose } \\
\text { agar }\end{array}$ & 0 & - \\
\hline Resistance to lysozyme & 0 & - \\
\hline \multicolumn{3}{|l|}{ Utilization of: } \\
\hline Citrate & 15 & - \\
\hline Propionate & 4 & - \\
\hline Decomposition of tyrosine & 9 & - \\
\hline \multicolumn{3}{|l|}{ Growth at: } \\
\hline $35^{\circ} \mathrm{C}$ & 98 & + \\
\hline $50^{\circ} \mathrm{C}$ & 0 & - \\
\hline
\end{tabular}

lysed by the phage; and they decomposed casein. Other properties were variable for the 20 strains.

The nomenclatural type strain of $B$. lentus (ATCC 10840) and seven other strains formed acid from arabinose, mannose, melibiose, raffinose, sucrose, and, with the exception of NRS 783 , xylose. The eight strains were not lysed by the bacteriophage and, with the exception of NRS strain 1571 , they did not decompose casein. Their reactions to the other tests were variable. According to the data presented in Table 4 , however, the 20 strains of $B$. firmus and the eight strains of $B$. lentus are connected by 18 intermediate strains. Except for a negative reaction on arabinose and, with the exception of NRS strain 1148, a positive reaction on casein, the 18 intermediate strains exhibit a gradual progression from the comparatively nonsaccharolytic, bacteriophage-sensitive strains of $B$. firmus to the more saccharolytic, phage-resistant strains of $B$. lentus.

The $\mathrm{G}+\mathrm{C}$ content of the DNA of eleven strains of $B$. firmus (Table 5) ranged from 39.1 to $44.7 \mathrm{~mol} \%$, with a mean of $42.5 \mathrm{~mol} \%$; the $\mathrm{G}+\mathrm{C}$ content of seven strains of $B$. lentus varied from 39.0 to $48.3 \mathrm{~mol} \%$, averaging 42.5 mol\%; and the $\mathrm{G}+\mathrm{C}$ content of 13 intermediate strains varied from 40.5 to $47.8 \mathrm{~mol} \%$, with a mean of $43.6 \mathrm{~mol} \%$.

\section{DISCUSSION}

According to the data presented here, strains of $B$. firmus and $B$. lentus share a distinctive group of morphological and physiological properties. Other physiological reactions and sensitivity to a bacteriophage for ATCC strain 14575 of $B$. firmus, however, divide our strains into two groups and connect the two groups by a significant number of intermediate strains in confirmation of Cowan's (4) observation that "The different kinds of bacteria are not sepa-

TABLE 3. Some criteria for separating strains of the Bacillus firmus-Bacillus lentus series from morphologically similar strains

\begin{tabular}{|c|c|c|c|c|c|}
\hline \multirow[b]{2}{*}{ Property } & \multicolumn{5}{|c|}{ Percent positive for: } \\
\hline & $\begin{array}{l}\text { B. firmus- } B \text {. } \\
\text { lentus, } 46 \\
\text { strains }\end{array}$ & $\begin{array}{l}\text { B. licheni- } \\
\text { formis, }{ }^{a} 27 \\
\text { strains }\end{array}$ & $\begin{array}{c}\text { B. subtilis, }{ }^{a} \\
71 \text { strains }\end{array}$ & $\begin{array}{c}\text { B. pumilus, }{ }^{a} \\
27 \text { strains }\end{array}$ & $\begin{array}{l}\text { B. coagulans, }{ }^{a} \\
22 \text { strains }\end{array}$ \\
\hline Production of acetoin & 0 & 100 & 97 & 96 & 100 \\
\hline Hydrolysis of starch & 100 & 100 & 100 & 0 & 100 \\
\hline Anaerobic growth & 0 & 100 & 0 & 0 & 95 \\
\hline $\begin{array}{l}\text { Growth on Sabouraud dex- } \\
\text { trose agar and/or broth }\end{array}$ & 0 & 100 & 100 & 100 & 100 \\
\hline Utilization of citrate & 15 & 100 & 93 & 96 & 18 \\
\hline Growth at $50^{\circ} \mathrm{C}$ & 0 & 100 & 72 & 59 & 100 \\
\hline
\end{tabular}

${ }^{a}$ Data from Gordon et al. (7). 
TABLE 4. Spectrum-like arrangement of strains of the Bacillus firmus-Bacillus lentus series based on physiological properties and bacteriophage sensitivity ${ }^{a}$

\begin{tabular}{|c|c|c|c|c|c|c|c|c|c|c|c|c|c|}
\hline \multirow{2}{*}{ Strain } & \multicolumn{7}{|c|}{ Acid from: } & \multirow{2}{*}{ SB } & \multirow{2}{*}{ C } & \multirow{2}{*}{ G } & \multirow{2}{*}{$\mathrm{U}$} & \multirow{2}{*}{$\mathrm{N}$} & \multirow{2}{*}{$\mathrm{P}$} \\
\hline & $\mathrm{Ar}$ & $\mathrm{Ma}$ & $\mathrm{Me}$ & $\mathrm{Ra}$ & So & $\mathrm{Su}$ & $\mathrm{Xy}$ & & & & & & \\
\hline \multirow{2}{*}{\multicolumn{14}{|c|}{$\begin{array}{l}\text { B. firmus } \\
\text { ATCC }\end{array}$}} \\
\hline & & & & & & & & & & & & & \\
\hline 8247 & - & - & - & - & - & + & - & + & + & + & - & + & + \\
\hline 14575 & - & - & - & - & - & + & - & + & + & + & - & + & + \\
\hline \multicolumn{14}{|l|}{ NRS } \\
\hline 613 & - & - & - & - & - & + & - & + & + & + & - & + & + \\
\hline 853 & - & - & - & - & - & + & - & + & + & + & - & + & + \\
\hline 854 & - & - & - & - & - & + & - & + & + & \pm & - & + & + \\
\hline 855 & - & - & - & - & - & + & - & + & + & + & - & + & + \\
\hline 858 & - & - & - & - & - & + & - & + & + & \pm & - & + & + \\
\hline 860 & - & - & - & - & - & + & - & + & + & + & - & + & + \\
\hline 861 & - & - & - & - & - & + & - & + & + & + & + & + & + \\
\hline 1070 & - & - & - & - & - & + & - & + & + & + & + & + & + \\
\hline 1119 & - & - & - & - & - & + & - & + & + & + & - & + & + \\
\hline 1131 & - & - & - & - & - & + & - & + & + & + & - & + & + \\
\hline 1132 & - & - & - & - & - & + & - & + & + & + & - & + & - \\
\hline 1152 & - & - & - & - & - & + & - & + & + & + & - & - & - \\
\hline 1560 & - & - & - & - & - & + & - & + & + & + & - & - & + \\
\hline 1561 & - & - & - & - & - & + & - & + & + & - & - & - & + \\
\hline 1563 & - & - & - & - & - & + & - & + & + & - & - & - & + \\
\hline 1567 & - & - & - & - & - & + & - & + & + & + & - & - & - \\
\hline 1568 & - & - & - & - & - & + & - & + & + & + & - & - & + \\
\hline 1576 & - & - & - & - & - & + & - & + & + & + & - & - & + \\
\hline \multicolumn{14}{|c|}{ Intermediate } \\
\hline \multicolumn{14}{|c|}{ NRS } \\
\hline 1369 & - & - & - & - & - & \pm & - & - & + & + & - & - & - \\
\hline 1329 & - & - & - & - & - & + & - & - & + & + & + & - & - \\
\hline 1370 & - & - & - & - & - & - & - & - & + & + & - & - & - \\
\hline 1148 & $-{ }^{b}$ & + & - & - & - & + & - & + & - & + & - & - & - \\
\hline 1573 & - & + & - & - & - & - & - & - & + & + & - & - & - \\
\hline 749 & - & + & - & - & - & + & - & $\mathrm{v}^{c}$ & + & \pm & + & + & - \\
\hline 1147 & - & + & - & - & - & + & - & - & + & $\overline{+}$ & - & - & - \\
\hline 1564 & - & + & - & - & - & + & - & - & + & \pm & - & - & + \\
\hline 1151 & - & - & - & - & - & + & + & - & + & - & - & + & - \\
\hline 1575 & - & - & - & + & - & + & - & + & + & + & - & - & + \\
\hline 1572 & - & - & + & + & - & + & - & + & + & + & - & - & + \\
\hline 1562 & - & + & + & - & - & + & - & - & + & \pm & - & - & - \\
\hline 1574 & - & + & + & - & - & + & + & - & + & \pm & - & - & - \\
\hline 1149 & - & + & + & \pm & - & + & - & + & + & + & - & - & - \\
\hline 1570 & - & + & + & - & - & + & - & - & + & \pm & - & - & - \\
\hline 1569 & - & + & + & - & + & + & + & - & + & + & - & + & - \\
\hline 1565 & - & + & + & + & - & + & \pm & - & + & + & - & - & + \\
\hline 1566 & - & + & + & + & - & + & + & - & + & + & - & - & - \\
\hline \multirow{2}{*}{\multicolumn{14}{|c|}{$\begin{array}{l}\text { B. lentus } \\
\text { ATCC }\end{array}$}} \\
\hline & & & & & & & & & & & & & \\
\hline 10840 & + & + & + & + & - & + & + & - & - & - & + & - & + \\
\hline 10841 & + & + & + & + & - & + & + & - & - & - & + & - & - \\
\hline \multicolumn{14}{|l|}{ NRS } \\
\hline 670 & + & + & + & + & + & + & + & - & - & \pm & + & - & + \\
\hline 769 & + & + & + & + & + & + & + & - & - & - & + & + & - \\
\hline 783 & + & + & + & + & + & + & - & - & - & + & - & + & - \\
\hline 883 & + & + & + & + & - & + & + & - & - & - & + & - & - \\
\hline 1262 & + & + & + & + & - & + & \pm & - & - & - & + & - & - \\
\hline 1571 & + & + & + & + & - & + & + & - & + & - & - & + & - \\
\hline
\end{tabular}

a Abbreviations: Ar, arabinose; Ma, mannose; Me, melibiose; Ra, raffinose; So, sorbitol; Su, sucrose; Xy, xylose; SB, sensitive to bacteriophage; $\mathrm{C}$, decomposition of casein; $\mathrm{G}$, decomposition of gelatin; $\mathrm{U}$, production of urease; $\mathrm{N}$, reduction of nitrate to nitrite; $\mathrm{P}$, deamination of phenylalanine.

${ }^{b}$ Substrate medium for carbohydrates inoculated with strain 1148 was nutrient agar without $3 \% \mathrm{NaCl}$.

${ }^{c}$ Sensitivity of strain 749 to bacteriophage was variable, sometimes positive, and other times negative. 
TABLE 5. DNA base composition of some strains of the Bacillus firmus-Bacillus lentus series

\begin{tabular}{|c|c|c|}
\hline \multirow{2}{*}{ Strain $^{a}$} & \multicolumn{2}{|c|}{$\mathrm{Mol} \% \mathrm{G}+\mathrm{C}$} \\
\hline & Laboratory $1^{b}$ & Laboratory $2^{c}$ \\
\hline \multicolumn{3}{|l|}{$\begin{array}{l}\text { B. firmus } \\
\text { ATCC }\end{array}$} \\
\hline 8247 & $43.2,40.7$ & \\
\hline 14575 & 43.7 & 43.7 \\
\hline \multicolumn{3}{|l|}{ NRS } \\
\hline 853 & 42.7 & \\
\hline 854 & 44.6 & \\
\hline 855 & 40.0 & \\
\hline 860 & 45.4 & \\
\hline 1070 & 44.4 & \\
\hline 1119 & 41.7 & \\
\hline 1132 & 39.0 & 42.9 \\
\hline 1152 & 40.0 & \\
\hline 1561 & 42.2 & \\
\hline \multicolumn{3}{|l|}{ Intermediate } \\
\hline \multicolumn{3}{|l|}{ NRS } \\
\hline 1329 & 43.9 & \\
\hline 749 & & 47.8 \\
\hline 1147 & 42.2 & \\
\hline 1564 & & $43.2,43.7$ \\
\hline 1151 & 42.9 & \\
\hline 1575 & & 45.6 \\
\hline 1572 & & 44.1 \\
\hline 1562 & & 43.4 \\
\hline 1574 & & 44.1 \\
\hline 1149 & 42.4 & \\
\hline 1570 & 40.5 & \\
\hline 1565 & 42.4 & \\
\hline 1566 & 43.7 & \\
\hline \multicolumn{3}{|l|}{ B. lentus } \\
\hline ATCC 10840 & 42.2 & \\
\hline \multicolumn{3}{|l|}{ NRS } \\
\hline 670 & $39.0,39.0$ & \\
\hline 769 & 40.7 & \\
\hline 783 & 47.3 & 48.3 \\
\hline 883 & 42.2 & \\
\hline 1262 & 42.4 & 42.9 \\
\hline 1571 & 42.9 & \\
\hline
\end{tabular}

${ }^{a}$ Arranged in same order as in Table 4.

${ }^{b}$ Determinations made in the laboratory of W. E. Kloos, North Carolina State University, Raleigh, N. C.

${ }^{c}$ Determinations made in this laboratory.

rated by sharp divisions but by slight and subtle differences in characters so that they seem to blend into each other and resemble a spectrum." A microbial series, or spectrum, is an informal category in taxonomy (8) between subgenus and species. Because we were unable to find a group of properties by which the strains of $B$. firmus and $B$. lentus could be cleanly divided, we believe that these strains provide a good illustration of a microbial series. Connected by intermediate strains, $B$. firmus and $B$. lentus merge and form a spectrum, or series, of strains.

Bacterial spectra, needless to say, are difficult to classify and lead to endless controversy among taxonomists. The examination of one or two strains from each end of a spectrum, or series of strains, will show distinct differences between them, differences that fade into insignificance when more strains are observed. (Beware of the representation of a species by one or two strains!) The intermediate strains cannot be ignored; they exist and must be incorporated in a classification.

Our present knowledge of our 46 strains of the $B$. firmus-B. lentus series supports a lumper's recommendation that all 46 strains be assigned to the same species and that the species $B$. firmus (the oldest species name represented) be defined by the following group of characteristics: gram-positive, motile rods; ellipsoidal, central or paracentral spores that do not swell the sporangia appreciably; $\mathrm{G}+\mathrm{C}$ content of the DNA varies from 39.0 to $48.3 \mathrm{~mol} \%$. The cultures are catalase positive and sensitive to lysozyme. They hydrolyze starch, form acid from glucose and mannitol, and grow in 7\% $\mathrm{NaCl}$ broth and at $35^{\circ} \mathrm{C}$. They do not grow anaerobically, nor on Sabouraud dextrose agar and/or broth, nor at $50^{\circ} \mathrm{C}$. Their egg-yolk reaction is negative; they do not utilize citrate or propionate, do not decompose tyrosine, and do not form acetoin or dihydroxyacetone. Variations in one or two of these properties by a strain would not prevent the strain's assignment to $B$. firmus.

The study of spore surfaces of strains of 20 species of Bacillus by Bradley and Franklin (1) suggested that the surface configurations might be useful in characterizing some species. The examinations reported here did not offer any means of separating strains of the $B$. firmus-B. lentus spectrum and did not contradict our belief that these strains belong to one species.

In contrast to the $\mathrm{G}+\mathrm{C}$ content of the DNA (as determined by the thermal melting point) of strains of many species of microorganisms, the range of 39.0 to $48.3 \mathrm{~mol} \%$ observed for 31 of our 46 strains seems unusually wide. For strains of Bacillus cereus, Bacillus stearothermophilus, and $B$. subtilis, however, equally wide ranges have been reported (11).

\section{ACKNOWLEDGMENTS}

This study was supported by grants from Novo Industri A/S, Bagsvaerd, Denmark, and Johnson \& Johnson, New Brunswick, N.J.

We are grateful for the help and instruction of W. E. Kloos in making the deoxyribonucleic acid determinations, and for the editorial suggestions of H. P. R. Seeliger. 


\section{REPRINT REQUESTS}

Address reprint requests to: Dr. Ruth E. Gordon, Waksman Institute of Microbiology, Rutgers University, P.O. Box 759, Piscataway, NJ 08854.

\section{LITERATURE CITED}

1. Bradley, D. E., and J. G. Franklin. 1958. Electron microscope survey of the surface configuration of spores of the genus Bacillus. J. Bacteriol. 76:618-630.

2. Brown, W. L., J. Z. Ordal, and O. H. Halvorson. 1957. Production and cleaning of spores of putrefactive anaerobe 3679. Appl. Microbiol. 5:156-159.

3. Collins, C. H. 1964. Microbiological methods. Butterworths, London.

4. Cowan, S. T. 1974. Cowan and Steel's manual for the identification of medical bacteria, 2nd ed. Cambridge University Press.

5. Gibson, T. 1935. The urea-decomposing microflora of the soils. I. Description and classification of the organisms. Zentralbl. Bakteriol. Parasitenkd. Infektionskr. Hyg. Abt. 2 92:364-380.

6. Gibson, T., and R. E. Gordon. 1974. Bacillus Cohn 1872, p. 529-550. In R. E. Buchanan and N. E. Gibbons (ed.), Bergey's manual of determinative bacteriology, 8th ed. The Williams \& Wilkins Co., Baltimore.

7. Gordon, R. E., W. C. Haynes, and C. H-N. Pang. 1973. The genus Bacillus. Agriculture Handbook no. 427. U. S. Dept. of Agriculture, Washington, D.C.

8. Lapage, S. P., P. H. A. Sneath, E. F. Lessel, V. B. D. Skerman, H. P. R. Seeliger, and W. A. Clark. 1975. International code of nomenclature of bacteria. American Society for Microbiology, Washington, D.C.

9. Marmur, J. 1961. A procedure for the isolation of deoxy- ribonucleic acid from micro-organisms. J. Mol. Biol. 3:208-218.

10. Marmur, J., and P. Doty. 1962. Determination of the base composition of deoxyribonucleic acid from its thermal denaturation temperature. J. Mol. Biol. 4:109-118.

11. Normore, W. M. 1973. Guanine-plus-cytosine (GC) composition of the DNA of bacteria, fungi, algae and protozoa, p. 585-740. In A. I. Laskin and H. A. Lechevalier (ed.), Handbook of microbiology, vol. 2. CRC Press, Cleveland.

12. Pacheco, G., and M. D. Santos. 1950. Sobre um germen pigmentado do xarque rosado. Rev. Mil. Remonta Vet. 10:75-78.

13. Proom, H., and B. C. J. G. Knight. 1955. The minimal nutritional requirements of some species in the genus Bacillus. J. Gen. Microbiol. 13:474-480.

14. Sacks, L. E., and G. Alderton. 1961. Behavior of bacterial spores in aqueous-polymer two-phase systems. J. Bacteriol. 82:331-341.

15. Smith, N. R., R. E. Gordon, and F. E. Clark. 1946 Aerobic mesophilic sporeforming bacteria. Miscellaneous Publication no. 559. U. S. Dept. of Agriculture, Washington, D.C.

16. Smith, N. R., R. E. Gordon, and F. E. Clark. 1952. Aerobic sporeforming bacteria. Agriculture Monograph no. 16. U.S. Dept. of Agriculture, Washington, D.C.

17. Turner, M., and D. I. Jervis. 1968. The distribution of pigmented Bacillus species in saltmarsh and other saline and non-saline soils. Nova Hedwigia 16:293297.

18. Werner, W. 1933. Botanische Beschreibung häufiger am Buttersäureabbau beteiligter sporenbildender Bakterienspezies. Zentralbl. Bakteriol. Parasitenkd. Infektionskr. Hyg. Abt. 2 87:446-475. 